\title{
Mechanisims of asthma and allergic disease - 1074. Prebiotics in infants for prevention of allergic disease and hypersensitiivity
}

John Sinn

From 2nd WAO International Scientific Conference (WISC 2012)

Hyderabad, India. 6-9 December 2012

\section{Background}

Prebiotics (promote growth of 'healthy' bacteria) added to infant feeds have the potential to prevent sensitisation of infants to dietary allergens.

\section{Methods}

Standard methods of the Cochrane Neonatal Review Group were used. Searches were updated October 2011. Randomised and quasi-randomised controlled trials that compared a prebiotic to control were eligible.

\section{Results}

Three studies enrolling 1315 infants and reporting outcomes of 1126 infants (85\%) were included. Several ongoing studies and completed studies with no reported allergy results were identified. Overall, one study reported a significant reduction in asthma (134 infants; RR 0.31, 95\% CI 0.14, 0.96; RD -0.13, 95\% CI -0.25, -0.01; NNT 7.7) but no significant difference in urticaria (134 infants, RR $0.15,95 \%$ CI $0.02,1.16)$ to 2 years. Meta-analysis of 3 studies found a significant reduction in infant eczema (1126 infants, RR 0.64, 95\%CI 0.44, 0.94; RD -0.04, 95\%CI -0.07, -0.01 ; NNT 25) although there was moderate heterogeneity between studies. In subgroup analysis, individual studies reported a significant reduction in asthma and eczema to 2 years - in infants at high risk of allergy fed an extensively hydrolysed formula; and a reduction in infant eczema in low risk infants fed a cow's milk formula. The studies reporting reductions in asthma or eczema used GOS/FOS combinations, one with added acidic OS, at a concentration $0.8 \mathrm{~g} / 100 \mathrm{ml}$ of oligosaccharide.

Obstetrics, Gynaecology and Neonatology, University of Sydney, Sydney, Australia

C) Biomed Central

\section{Conclusions}

Further evidence is required before a prebiotic can be routinely recommended for prevention of allergy. A well powered, independent trial is required to answer this question.

Published: 23 April 2013

\section{doi:10.1186/1939-4551-6-S1-P71}

Cite this article as: Sinn: Mechanisims of asthma and allergic disease 1074. Prebiotics in infants for prevention of allergic disease and hypersensitiivity. World Allergy Organization Journal 2013 6(Suppl 1):P71.
Submit your next manuscript to BioMed Central and take full advantage of:

- Convenient online submission

- Thorough peer review

- No space constraints or color figure charges

- Immediate publication on acceptance

- Inclusion in PubMed, CAS, Scopus and Google Scholar

- Research which is freely available for redistribution
C Biomed Central 